Glosy Studia luridica Lublinensia vol. XXVI, 2, 2017 DOI: 10.17951/sil.2017.26.2.177

\title{
Adam Górski
}

Uniwersytet Jagielloński w Krakowie adam.gorski@uj.edu.pl

\section{Glosa do postanowienia Sądu Najwyższego z dnia 28 kwietnia 2016 r. (I KZP 24/15)}

\author{
The Commentary on the Supreme Court's Verdict \\ of 28 April 2016 (I KZP 24/15)
}

\section{STRESZCZENIE}

Autor zgadza się z tezą orzeczenia, zgodnie z którą „ochrona prawna należna funkcjonariuszowi publicznemu, przyznana lekarzowi w art. 44 ustawy z 5 grudnia 1996 r. o zawodach lekarza i lekarza dentysty oraz w art. 5 ustawy z dnia 8 września 2006 r. o Państwowym Ratownictwie Medycznym, nie obejmuje sytuacji innych niż udzielanie pomocy doraźnej (a więc udzielanie pierwszej pomocy i podejmowanie medycznych czynności ratunkowych) lub pomocy lekarskiej wtedy, gdy zwłoka w jej udzieleniu mogłaby spowodować niebezpieczeństwo utraty życia, ciężkiego uszkodzenia ciała lub ciężkiego rozstroju zdrowia oraz w innych wypadkach niecierpiących zwłoki”.

Słowa kluczowe: znieważenie; lekarz

[...] ochrona prawna należna funkcjonariuszowi publicznemu, przyznana lekarzowi w art. 44 ustawy z 5 grudnia 1996 r. o zawodach lekarza i lekarza dentysty oraz w art. 5 ustawy z dnia 8 września 2006 r. o Państwowym Ratownictwie Medycznym, nie obejmuje sytuacji innych niż udzielanie pomocy doraźnej (a więc udzielanie pierwszej pomocy i podejmowanie medycznych czynności ratunkowych) lub pomocy lekarskiej wtedy, gdy zwłoka w jej udzieleniu mogłaby spowodować niebezpieczeństwo utraty życia, ciężkiego uszkodzenia ciała lub ciężkiego rozstroju zdrowia oraz $\mathrm{w}$ innych wypadkach niecierpiących zwłoki. Za wykonywanie czynności w tym zakresie uznać trzeba także działanie zmierzające bezpośrednio do ich udzielenia od chwili odebrania zindywidualizowanego wezwania do ich udzielenia lub od chwili podjęcia przez lekarza stosownych działań z własnej inicjatywy. Ta ochrona prawna nie obejmuje okresu pełnienia przez 
lekarza dyżuru w szpitalnym oddziale ratunkowym, jeśli polega on tylko na oczekiwaniu na wezwanie do wyjazdu załogi karetki pogotowia ratunkowego.

Sąd Najwyższy, odmawiając odpowiedzi na konkretne pytanie prawne ${ }^{1}$, trafnie zauważył, iż przedstawiony problem dotyczył przede wszystkim swoistej techniki legislacyjnej ${ }^{2}$, nie zaś zasadniczej wykładni prawa. W uzasadnieniu glosowanego orzeczenia znajduje się jednak również wskazanie, w jaki sposób prawidłowo rozumieć art. 44 ustawy z dnia 5 grudnia 1996 r. o zawodach lekarza i lekarza dentysty ${ }^{3} \mathrm{w}$ jego relacji do art. $226 \S 1$ k.k. Choć przede wszystkim druga kwestia była przedmiotem postanowienia Sądu Najwyższego, to niniejsze opracowanie dotyczyć będzie zarówno pierwszego, jak i drugiego problemu, wykraczając nieco poza klasyczną formułę komentowania orzeczenia.

I.

Odpowiedzialność karna, a tym samym jej zakres, określana jest w przypadku ochrony lekarza, ,jak funkcjonariusza”, w sposób nietypowy i mogący rodzić szereg kontrowersyjnych konsekwencji w sferze stosowania prawa. Zajmując się konstrukcją przepisu karnego, doktryna prawa i praktyka analizuje taki sposób stanowienia prawa, w którym przepis samoistnie reguluje zagadnienie odpowiedzialności karnej ${ }^{4}$. Co najmniej tyle samo uwagi poświęca się rozwiązaniom ustawodawczym, w których przepis prawa karnego odsyła do przepisów ustawowych lub podstawowych, w tym blankietowych. Ten ostatni model ustawodawczy może

${ }^{1}$ „1) Czy lekarz, który pełni dyżur w szpitalnym oddziale ratunkowym jako członek załogi karetki pogotowia ratunkowego, oczekując na wezwanie do wyjazdu, jest lekarzem wykonującym czynności w ramach świadczeń pomocy doraźnej lub w sytuacji, gdy zwłoka w udzieleniu pomocy lekarskiej mogłaby spowodować niebezpieczeństwo utraty życia, ciężkiego uszkodzenia ciała lub ciężkiego rozstroju zdrowia lub w innym przypadku niecierpiącym zwłoki - w rozumieniu art. 44 w związku z art. 30 ustawy z 5 grudnia 1996 roku o zawodach lekarza i lekarza dentysty (Dz.U. z 2015 r., poz. 464), 2) jeżeli tak, to czy sprawca znieważający lekarza znajdującego się w takiej sytuacji dopuszcza się czynu zabronionego z art. 226 § 1 Kodeksu karnego?”.

${ }^{2}$ Jak wynika z uzasadnienia uchwały I KZP 24/15 na stronie ww.sn.pl, np. s. 7.

${ }^{3}$ Dz.U. z 1997 r., nr 28, poz. 152 ze zm., dalej jako: u.z.l. Art. 44. u.z.l.: „Lekarzowi, który wykonuje czynności w ramach świadczeń pomocy doraźnej lub w przypadku, o którym mowa w art. 30, przysługuje ochrona prawna należna funkcjonariuszowi publicznemu".

${ }^{4}$ Zob. zwłaszcza: K. Buchała, W. Wolter, Wykład prawa karnego na podstawie kodeksu karnego z 1969 r., cz. 1, Kraków 1970, s. 16-31; I. Andrejew, Ustawowe znamiona czynu. Typizacja i kwalifikacja przestęstw, Warszawa 1978, s. 16-18; J. Majewski, Budowa przepisów prawa karnego i norm w nich zawartych, [w:] System Prawa Karnego, t. 2: Źródła prawa karnego, red. T. Bojarski, Warszawa 2011, s. 440-446. 
rodzić cały szereg problemów w procesie stosowania prawa. Przede wszystkim dotyczą one legitymizacji do tworzenia przepisów blankietowych, odsyłających do rozporządzeń. Ten ostatni problem związany jest niewątpliwie z konstytucyjną zasadą podziału władz ${ }^{5}$. Odesłania do innych ustaw wynikają (równie klarownie, co odesłania do rozporządzeń) w sposób oczywisty z samej konstrukcji przepisu karnego. Sąd Najwyższy wskazywał między innymi, że z zasady określoności znamion przestępstwa wynika postulat stylistycznej jasności w formułowaniu przepisu i jednoznaczności jego treści tak, aby praktyka sądów nie rozstrzygała o tym, co jest przestępstwem i aby w praktyce tej nie dochodziło - w wyniku interpretacji rozszerzającej - do karania za czyny podobne, nieobjęte jednak zakazem ustawy karnej ${ }^{6}$.

$\mathrm{Z}$ zasady przepisy odsyłające odpowiednio nie powodują bardziej poważnych kontrowersji w sferze stosowania prawa niż przepisy karne w sposób zupełny regulujące problematykę odpowiedzialności karnej. Dopuszczalności, a niekiedy konieczności, odpowiedniego stosowania przepisów w obrębie prawa karnego materialnego nie kwestionuje się $\mathrm{w}$ doktrynie prawa ${ }^{7}$.

$\mathrm{Z}$ powyższego trudno jest jednoznacznie wywnioskować, czy formuła użyta przez ustawodawcę $\mathrm{w}$ art. 44 u.z.l. jest legislacyjnie poprawnym sposobem stanowienia przepisów prawa karnego. Doktryna prawa karnego raczej pobieżnie analizuje ten problem ${ }^{8}$. Konkretnie też kwestia ochrony lekarza, jak funkcjonariusza publicznego, nie była szeroko, zaś z całą pewnością dogłębnie, rozważana w piśmiennictwie prawniczym. Analizowany tu problem jest właściwie tylko sygnalizowany ${ }^{9}$.

$\mathrm{Z}$ jednej strony można oczywiście wnioskować niejako a contrario o niedopuszczalności analizowanego rozwiązania. $Z$ drugiej jednak należy stwierdzić, iż ustawodawca ma swobodę normatywną w kreowaniu przepisów prawa, w tym karnego, zaś nie każde unormowanie niezgodne z zasadami techniki prawodaw-

${ }^{5}$ Zob. A. Zoll, Znaczenie konstytucyjnej zasady podziału władzy dla prawa karnego materialnego, „Ruch Prawniczy, Ekonomiczny i Socjologiczny” 2006, nr 2, s. 323-335.

${ }^{6}$ Zob. np. postanowienie SN z dnia 3 października 2008 r., III KK 176/08, „Prokuratura i Prawo" 2009, nr 7, poz. 8 (dodatek: Orzecznictwo), s. 6.

${ }^{7}$ Zob. np. Z. Siwik, „Odpowiednie” stosowanie przepisów prawa karnego w prawie karnym skarbowym, „Przegląd Prawa i Administracji” 1987, nr 23, s. 97-121.

${ }^{8}$ Zob. J. Wyrembak, Pojęcie funkcjonariusza publicznego w prawie karnym, „Państwo i Prawo" 2007 , z. 4, s. $85-87$.

${ }^{9}$ Zob. K. Sakowski, Komentarz do art. 44, [w:] Ustawa o zawodach lekarza i lekarza dentysty. Komentarz, red. E. Zielińska, Warszawa 2008, s. 618-619; E. Zatyka, Status osób wykonujących zawody medyczne w plaszczyźnie prawnokarnej, [w:] Nauki penalne wobec szybkich przemian socjokulturowych. Księga jubileuszowa Profesora Mariana Filara, red. A. Adamski, J. Bojarski, P. Chrzczonowicz, M. Leciak, Torun 2012, s. 156-169; J. Kulesza, Prawnokarne środki ochrony przed przemoca przyshugujace lekarzowi w zwiąku z wykonywaniem zawodu-zagadnienia podstawowe, „Prawo i Medycyna” 2010, nr 2, s. 68-81. 
czej musi być uznane za w sposób oczywisty zakłócające proces stosowania prawa karnego. Ta swoboda normatywna ustawodawcy nie jest rzecz jasna nieograniczona. Ostatecznie wybór techniki prawodawczej warunkowany wydaje się być przede wszystkim nie tyle konwencją redakcji przepisu przewidującego odpowiedzialność karną, ile postulatem precyzyjności prawa karnego (lex certa). Względy techniki prawodawczej uważane są (również z racji statusu prawnego odnośnego aktu prawnego) jedynie za dyrektywy (wskazówki) dla ustawodawcy ${ }^{10}$.

Nie zmienia to oczywiście faktu, że doktryna prawa karnego oraz orzecznictwo zajmowały się dotąd niemal wyłącznie odesłaniami wynikającymi z przepisów prawa karnego. W wypadku ochrony lekarza, jak funkcjonariusza (oraz innych zawodów medycznych, co nie stanowi jednak istoty rozważań), mamy do czynienia ze zjawiskiem odwrotnym. Precyzując, polega ono na takim formułowaniu przepisów prawa publicznego, które w sposób ogólny, jak się wydaje metodą odpowiedniego stosowania, rozszerza ochronę prawną (w tym lege non distinguente prawnokarną), należną funkcjonariuszowi publicznemu, na inne podmioty. Jeśli chodzi o regulacje prawne zawodów medycznych, de lege lata przepisami o podobnej do art. 44 u.z.l. konstrukcji są art. 11 ust. 2 ustawy z dnia 15 lipca 2011 r. o zawodach pielęgniarki i położnej ${ }^{11}$, jak również art. 5 ustawy z dnia 8 września 2006 r. o Państwowym Ratownictwie Medycznym ${ }^{12}$.

Brak tam powołania się na konkretne przepisy prawa karnego, do których przepis ten $\mathrm{w}$ istocie, jak należy sądzić, odsyła. Czy prawodawca miał więc wyraźną intencję rozszerzenia ochrony prawnokarnej służącej funkcjonariuszowi publicznemu na lekarza w określonych w art. 44 u.z.l. sytuacjach? Nie sposób znaleźć racjonalne argumenty za wyłączeniem ochrony prawnokarnej z ochrony prawnej przysługującej lekarzowi analogicznie do funkcjonariusza publicznego. Umiejscowienie przepisu w sensie techniczno-legislacyjnym poza systemem prawa karnego nie przesądza o braku jego mocy walidacyjnej. Decydujące będzie tu właściwe odczytanie intencji ustawodawcy. Mimo pewnych wątpliwości intertemporalnych (o czym niżej), jest ona jednoznaczna. Wynika to też z postanowienia Sądu Najwyższego z dnia 7 września 2000 r. $^{13}$

Inna zresztą, niż rodząca po stronie sprawcy odpowiedzialność prawnokarną, wykładnia przepisu art. 44 u.z.l. mogłaby spotkać się z zarzutem traktowania go per non est. Wyjąwszy przypadek prawa karnego, polski system prawa dodatkowo chroni funkcjonariusza publicznego wyłącznie pośrednio.

Nie bez znaczenia dla oceny prawidłowości legislacyjnej regulacji dotyczących ochrony lekarza, jak funkcjonariusza publicznego, jest wspomniany wyżej

${ }^{10}$ Zob. M. Hauser, Odpowiednie stosowanie przepisów prawa-uwagi porządkujące, „Przegląd Prawa i Administracji” 2005, t. 65, s. 154.

${ }^{11}$ Dz.U. z 2011 r., nr 174, poz. 1039.

${ }^{12}$ Dz.U. z 2006 r., nr 191, poz. 1410.

${ }^{13}$ I KZP 26/00, OSNKW 2000, nr 9-10. 
problem intertemporalny. Art. 120 § 11d k.k. stanowił mianowicie, iż osoba, na którą rozciąga się ochrona przewidziana dla funkcjonariuszy publicznych, jest funkcjonariuszem publicznym. Brak takiego przepisu w obowiązującym Kodeksie karnym, zwłaszcza wobec konieczności zawężającego traktowania katalogu z art. $115 \S 13$ k.k., mógłby wskazywać, iż w nowym stanie prawnym wyłączona została również ochrona prawnokarna lekarza jako funkcjonariusza. Do przeciwnej interpretacji przychylił się jednak Sąd Najwyższy w postanowieniu z dnia 7 września 2000 r. Stanowisko to spotkało się pośrednio z krytyką doktryny prawa $\mathrm{z}$ uwagi na niedostateczne jej zdaniem rozważenie treści art. $12 \S 2$ ustawy z dnia 6 czerwca 1997 r. - przepisy wprowadzające Kodeks karny ${ }^{14}$, który stanowi, iż w razie wątpliwości, czy ma być stosowane prawo dotychczasowe czy Kodeks karny, stosuje się Kodeks karny ${ }^{15}$. Trzeba tu z całą mocą podkreślić, iż to brzmienie art. 44 u.z.l. przesądza o ochronie prawnokarnej lekarza. Następcze wobec tego przepisu zmiany Kodeksu karnego nie powinny mieć na zakres tej ochrony wpływu, ponieważ wydaje się, iż ustawodawca posłużył się w tym wypadku odpowiednim stosowaniem ustawy. Oznacza to rzecz jasna, że lekarz nie musi posiadać cechy „funkcjonariusz publiczny”, aby zostać objętym ochroną $\mathrm{z}$ art. $226 \S 1$ k.k.

II.

Wątpliwości objaśniane przez Sąd Najwyższy odnosiły się przede wszystkim do tego, czy ochrona prawnokarna wynikająca z art. 44 u.z.l. dotyczy każdej sytuacji, w której lekarz co prawda nie wykonuje czynności, o których mowa w tym artykule, ale pozostaje w sytuacji, w której wykonywanie tych czynności może się w każdej chwili zaktualizować. Dotyczy to każdej okoliczności, w której można mówić o stosowaniu u.z.l., w jakiej lekarz w danej chwili nie wykonuje czynności, o których mowa $\mathrm{w}$ art. 44, ale pozostaje niejako „w bezpośredniej możliwości” ich wykonywania. Dla przykładu można tu podać sporządzanie dokumentacji medycznej w klinice lub innym zakładzie leczniczym, zwykły odpoczynek w dyżurce lub gabinecie, wykonywanie w danej chwili badań klinicznych niezwiązanych z konkretnym procesem leczniczym.

Prostego rozwiązania nie przynosi konstrukcja u.z.l., która to ustawa reguluje wykonywanie zawodu lekarza. Zakres temporalny jej stosowania nie ogranicza się więc do świadczenia przezeń pracy lub pozostawania w gotowości do pracy. Teoretycznie ochrona lekarza, jak funkcjonariusza, dotyczy też tych „pozazawodowych" sytuacji.

${ }^{14}$ Dz.U. z 1997 r., nr 88, poz. 554.

${ }^{15}$ Zob. J. Wyrembak, op. cit., s. 86, bez powołania niniejszego orzeczenia. 
W związku z powyższym art. 44 u.z.l. można traktować jako problem interpretacyjny, mający źródło w wykładni gramatycznej. Odczytywany literalnie i zgodnie z dyrektywą języka potocznego przepis normowałby sytuacje, w których lekarz rzeczywiście i w danym momencie świadczy pomoc doraźną lub wykonuje obowiązki określone w art. 30 u.z.1. ${ }^{16}$ Interpretacja taka nie jest pozbawiona podstaw semantycznych, nie jest także jedyną możliwą. Słusznie podnosi się w doktrynie, iż dyrektywa języka ogólnego nie musi być wiodącą dyrektywą interpretacji prawa karnego ${ }^{17}$. Na idiomatyczność tekstu prawnego (zarówno w kontekście znaczeń wyrazów, jak i składni) zwraca się uwagę w piśmiennictwie $^{18}$. Sposób formułowania jednostek sensowych w podobnych sytuacjach przez ustawodawcę świadczyłby o używaniu tego typu formuły gramatycznej dla określenia pewnych sytuacji w ich postulatywnym, nie zaś konkretnym rozumieniu. Argumentacja ta wspierana jest również przez umiejscowienie przepisu art. 44 u.z.l. w jednostce redakcyjnej pt. Zasady wykonywania zawodu lekarza. Stanowią one zbiór wymaganych, ale niekoniecznie w każdej chwili aktualizowanych, reguł profesjonalnego postępowania. Zatem zdecydowanie trafne jest ustalenie prawne Sądu Najwyższego wyrażone w wyżej wymienionym postanowieniu I KZP 24/15, iż wykonywanie czynności, o których mowa w art. 44 u.z.l., dotyczy zarówno stanu zaktualizowanego, jak i potencjalnego (zwłaszcza możliwego do zaktualizowania „w każdej następnej chwili” lub „właśnie zaktualizowanego"). Nie oznacza to oczywiście, iż lekarz w każdej sytuacji chroniony jest tak, ,jak funkcjonariusz publiczny", ale rozstrzyga to nie art. 44 u.z.l., lecz sam art. $226 \S 1$ k.k. Ten ostatni stanowi bowiem, że dzieje się tak ,podczas i w związku" z pełnieniem obowiązków (dokonywaniem takich, jak wymienione w art. 44 u.z.1., świadczeń zdrowotnych). Jest to zresztą zapatrywanie zbieżne i z dotychczasowym orzecznictwem Sądu Najwyższego ${ }^{19}$, i z wyrokiem Trybunału Konstytucyjnego z dnia 11 października 2006 r., P 3/06 ${ }^{20}$. Wynika stąd, że brak jest groźby „nadmiernej” lub „rozmytej” ochrony lekarza, jak funkcjonariusza publicznego, za przestępstwo znieważenia. Przy tym użyta przez ustawodawcę koniunkcja nie musi oczywiście oznaczać absolutnej korelacji czasowej znieważenia lekarza oraz wykonywania przez lekarza czynności pomocy doraźnej lub czynności, o których stanowi art. 30 u.z.l., ale również sytuacje, w których czynności te już się zaktualizowały lub w najbliższym czasie się zaktualizują ${ }^{21}$.

\footnotetext{
${ }^{16}$ Por. również motywy uchwały I KZP 24/15 dostępnej na www.sn.pl.

${ }^{17}$ Tak np. P. Wiatrowski, Dyrektywy wyktadni prawa karnego materialnego w judykaturze Sądu Najwyższego, Warszawa 2013, s. 4.

${ }^{18}$ Zob. M. Zieliński, Wyktadnia prawa. Zasady, reguty, wskazówki, Warszawa 2012, s. 101.

${ }^{19}$ Zob. zwłaszcza: wyrok SN z dnia 9 lutego 2010 r., II KK 176/09.

${ }^{20}$ OTK-A 2006, nr 9, poz. 121.

${ }^{21}$ Tak też: postanowienie SN I KZP 24/15.
} 
Użyte przez Sąd Najwyższy sformułowanie „bezpośrednio zmierza” przypomina oczywiście definicję usiłowania. Można się w związku z tym spodziewać podobnych trudności związanych z precyzyjnym ustaleniem tego momentu. Choć wybór określenia kontekstu czasowo-sytuacyjnego prawnokarnej ochrony lekarza uznać należy za właściwy, to jednocześnie trzeba postulować szerokie rozumienie pojęcia „bezpośrednio zmierza”, niewiążące się z „początkiem dokonania", a więc udzielania świadczeń zdrowotnych, o których mowa w art. 44 u.z.l.

Warto w tym miejscu wyjść nieco poza pole ustaleń i rozważań Sądu Najwyższego. Wzmożonej ochronie prawnokarnej lekarza jako funkcjonariusza można zarzucić pewną niekonsekwencję. Aksjologiczną przesłanką wzmożonej ochrony prawnokarnej, przysługującej funkcjonariuszowi publicznemu, jest bowiem jego wzmożona odpowiedzialność. Nie jest to kwestia wyłącznie teoretyczna. Konsekwencją szczególnego statusu funkcjonariusza publicznego jest decyzja ustawodawcy odnośnie do wyższej niż w wypadku prywatnoskargowego znieważenia sankcji oraz publicznoskargowego trybu ścigania. Wzmożona ochrona, jako swoista „gratyfikacja prawna”, powinna być absolutnym korelatem wzmożonej odpowiedzialności ${ }^{22}$. Zasadnie zwraca się uwagę, że w wypadku lekarza brak jest wyraźnie tej drugiej, choć podlega on wzmocnionej odpowiedzialności jako osoba pełniąca funkcję publiczną. Wypada zastanowić się, czy jest to bezwzględny warunek wzmożonej kryminalizacji. Takiej tezie przeczyłaby już prima facie analogiczna do funkcjonariusza publicznego ochrona „osoby przybranej do pomocy funkcjonariuszowi publicznemu”. Brak jest w jej wypadku „szczególnej odpowiedzialności prawnej”. W wypadku lekarza, co prawda, system prawa nie przewiduje klasycznej odpowiedzialności urzędniczej za nadużycie władzy, lecz faktem jest podobna do funkcjonariusza publicznego odpowiedzialność lekarza jako „osoby pełniącej funkcję publiczną”. Jego szczególny, wynikający z ustaw, status społeczny i zwłaszcza szczególne narażenie dóbr prawnych podczas wykonywania zawodu, nie mogą być kwestionowane. Nie wydaje się, by argument „równych praw - równych obowiązków” zdecydowanie sprzeciwiał się takiemu rozwiązaniu legislacyjnemu, polegającemu na rozciągnięciu na lekarza ochrony przysługującej funkcjonariuszowi publicznemu. Uzasadnianiem różnicowania (wzmożenia) stopnia ochrony lekarza jest, zdaniem E. Zielińskiej, m.in. szerokie spektrum czynności, które wykonuje ${ }^{23}$. Można więc konkludować, iż część tych czynności przesądza potrzebę wzmożonego stopnia ochrony prawnokarnej lekarza.

${ }^{22}$ Tak też: np. J. Wyrembak, op. cit., s. 86.

${ }^{23}$ Zob. E. Zielińska, Odpowiedzialność zawodowa lekarza i jej stosunek do odpowiedzialności karnej, Warszawa 2001, s. 34. 


\section{BIBLIOGRAFIA}

Andrejew I., Ustawowe znamiona czynu. Typizacja i kwalifikacja przestępstw, Warszawa 1978.

Buchała K., Wolter W., Wyktad prawa karnego na podstawie kodeksu karnego z 1969 r., cz. 1, Kraków 1970.

Hauser M., Odpowiednie stosowanie przepisów prawa - uwagi porządkujące, „Przegląd Prawa i Administracji” 2005, t. 65.

Kulesza J., Prawnokarne środki ochrony przed przemoca przyslugujące lekarzowi w związu z wykonywaniem zawodu - zagadnienia podstawowe, „Prawo i Medycyna” 2010, nr 2.

Majewski J., Budowa przepisów prawa karnego i norm w nich zawartych, [w:] System Prawa Karnego, t. 2: Źródta prawa karnego, red. T. Bojarski, Warszawa 2011.

Postanowienie SN z dnia 7 września 2000 r., I KZP 26/00, OSNKW 2000, nr 9-10.

Postanowienie SN z dnia 3 października 2008 r., III KK 176/08, „Prokuratura i Prawo” 2009, nr 7 , poz. 8 (dodatek: Orzecznictwo).

Sakowski K., Komentarz do art. 44, [w:] Ustawa o zawodach lekarza i lekarza dentysty. Komentarz, red. E. Zielińska, Warszawa 2008.

Siwik Z., „Odpowiednie” stosowanie przepisów prawa karnego w prawie karnym skarbowym, „Przegląd Prawa i Administracji” 1987, nr 23.

Ustawa z dnia 5 grudnia 1996 r. o zawodach lekarza i lekarza dentysty (Dz.U. z 1997 r., nr 28, poz. 152 ze zm).

Ustawa z dnia 6 czerwca 1997 r. - przepisy wprowadzające Kodeks karny (Dz.U. z 1997 r., nr 88, poz. 554).

Ustawa z dnia 8 września 2006 r. o Państwowym Ratownictwie Medycznym (Dz.U. z 2006 r., nr 191, poz. 1410).

Ustawa z dnia 15 lipca 2011 r. o zawodach pielęgniarki i położnej (Dz.U. z 2011 r., nr 174, poz. 1039).

Wiatrowski P., Dyrektywy wyktadni prawa karnego materialnego w judykaturze Sądu Najwyższego, Warszawa 2013.

Wyrembak J., Pojęcie funkcjonariusza publicznego w prawie karnym, „Państwo i Prawo” 2007, z. 4. Wyrok SN z dnia 9 lutego 2010 r., II KK 176/09.

Wyrok TK z dnia 11 października 2006 r., P 3/06, OTK-A 2006, nr 9, poz. 121.

Zatyka E., Status osób wykonujących zawody medyczne w płaszczyźnie prawnokarnej, [w:] Nauki penalne wobec szybkich przemian socjokulturowych. Ksiega jubileuszowa Profesora Mariana Filara, red. A. Adamski, J. Bojarski, P. Chrzczonowicz, M. Leciak, Torun 2012.

Zielińska E., Odpowiedzialność zawodowa lekarza i jej stosunek do odpowiedzialności karnej, Warszawa 2001.

Zieliński M., Wykładnia prawa. Zasady, reguły, wskazówki, Warszawa 2012.

Zoll A., Znaczenie konstytucyjnej zasady podziału władzy dla prawa karnego materialnego, „Ruch Prawniczy, Ekonomiczny i Socjologiczny" 2006, nr 2. 
Pobrane z czasopisma Studia Iuridica Lublinensia http://studiaiuridica.umes.pl Data: 26/04/2023 12:07:42

Glosa do postanowienia Sądu Najwyższego z dnia 28 kwietnia 2016 r. (I KZP 24/15)

\section{SUMMARY}

The author agrees with the thesis of the verdict according to which, "the legal protection that is due to a public official granted to a physician in Art. 44 of the Act of 5 December 1996 on the Professions of a Physician and a Dentist Physician and in Art. 5 of the Act of 8 September 2006 on National Medical Emergency Service does not cover situations other than providing shortterm assistance (i.e. providing first aid and performing emergency medical procedures) or medical assistance where any delay would result in exposing to danger of loss of life, grievous bodily harm or health disorder, and in other urgent cases".

Keywords: insult; physician 